Copyright (C) 2021 University of Bucharest Printed in Romania. All rights reserved

ISSN print: $1224-5984$

ISSN online: $2248-3942$
Rom Biotechnol Lett. 2021; 26(3): 2700-2706 doi: $10.25083 / \mathrm{rbl} / 26.3 / 2700.2706$

Received for publication, September, 4, 2020

Accepted, January, 16, 2021

\title{
Review
}

\section{Biotechnological potential of plant associated microorganisms}

\author{
SERGIU FENDRIHAN ${ }^{1,2 *}$, CRISTIAN-EMILIAN POP \\ ${ }^{1}$ Laboratory of Useful Organisms, Res. Institute for Plant Protection, Blvd. Ion Ionescu de la Brad, 8, \\ 013813, Bucharest, Romania \\ ${ }^{2}$ Faculty of Medicine, University “Vasile Goldis”, Bulevardul Revoluției 94, 310025, Arad, Romania \\ ${ }^{3}$ Department of Organic Chemistry, Biochemistry and Catalysis, Faculty of Chemistry, University of \\ Bucharest, 90 Panduri Str., 050663, Bucharest, Romania
}

\begin{abstract}
This paper shortly reviews the potential of plants associated microorganisms collectively termed "phytomicrobiome" (epiphytes, endophytes, root microbiome and phyllosphere microbiota), fungi and bacteria, that produce valuable molecules which can be use in pharma industry, in medicine and in different other industries as well as in environment protection and bioremediation. In the last ten years many papers on this subject were issued following scientific investigations, attracting the attention of the scientific community as an answer to some of our problems.
\end{abstract}

Keywords Endophytes, fungi, bacteria, medicine, agriculture, biotechnology.

To cite this article: FENDRIHAN S, POP CE. Biotechnological potential of plant associated microorganisms. Rom Biotechnol Lett. 2021; 26(3): 2700-2706. DOI: $10.25083 / \mathrm{rbl} / 26.3 / 2700-2706$ 


\section{Introduction}

Plant associated microorganisms are bacteria and fungi, some being symbionts, most of them commensals, and some being real phytopathogens, living outside plantsepiphytes, on leaves, stems and even roots, inside plants tissues and organs-endophytes, and in proximity of plants organs in soil, in the so called phyllosphere. Not only plants, but even animals and humans have inside and outside the organism an entire specific microbiome as part of a ecological niche of ecto- and endobionts. This fact shows the extraordinary complexity of the ecosystems, including the agroecosystems. In the conditions of climate change, of demographic boom, of the pollution of soil and water with chemicals, finding new environmental friendly solutions, compounds and technologies is a must for further development of our civilization. The development of such existing tehnologies as well as new ones is needed now more than ever, as the global population demographic growth is predicted to reach 9,2 billions in 2050 .

The microorganisms associated with plants, including with agricultural crops, can have applications in different fields of activity, with an entire scientific literature being now focused on it. The bacteria, fungi, and archaea were discovered to form communities on plants surfaces such as on leaves, stems, flowers, underground on roots, in the neighbourhood of roots, the so called epiphytes and endophytes- inside plant organs and tissues, without harming the host plant, using it as living environment. These endophytes are practically endobiotrophs (endobionts)-forming and endo-microbiome, which resembles the animal and human endo-microbiome, this is an inner habitat, a special ecological niche (endobionts) which is very interesting to study. Many epiphytes and endophytes have interesting metabolic capacities which can be use in diferent fields of human activity (NEWMAN and CRAGG, 2015). The plant microbiome is named phytomicrobiome, the root microbiome is partially derived from the bacteria and fungi from the rhizosphere, which can adhere to plant in rhizoplane (GAIERO et al, 2013).

The plant microbiome plays a multiple role in its relation with the host plant and with other microorganisms, being able to indirectly protect the plant against phytopathogens by biochemical mechanisms (BULGARELLI et al, 2013). The same authors shown that there is a selection of factors which is shaping the communities of microorganisms inside and outside of plants, for example the number of bacteria (the most important part of phylosphere microbiome) being $10^{6}-10^{7}$ microbes/sqm of foliar area. The microorganisms present in association with plants are Archaea (Euryarchaeota); bacteria (Acidobacteria, Actinobacteria, Bacteroidetes, Deinococcus-
Thermus, Firmicutes and Proteobacteria) and fungi (Ascomycota and Basidiomycota), (YADAV, 2017). An estimated appreciation of the total number of endophytic species being about one million, and each plant species contains one or more species of endophytes (STROBEL et DAISY, 2003). The endophytes seem not be harmful for plants but neither are they symbiotic (JALGAONWALA et al, 2011), although having a certain benefit for the host, as in pathogen protection (by releasing some antibiotics) and environmental stress tolerance (JALGAONWALA et al, 2011), they are considered an excellent source of bioactive products. An example of host plant is Urginea indica, a medicinal plant from India, from which were isolated endophytic fungi belonging to Hyphomycetes and Coelomycetes (KAMESWARI et al, 2015).

\section{Applications}

The endophytic bacteria and fungi can be used in different activities from plants stimulation, pigments producing, biocontrol agents, antimicrobials and antifungals, bioremediation, and many others (NAIR et PADMAVATHY, 2014). Other authors showed the importance of endophytic fungi in releasing important molecules for new drugs production (PRAKASH, 2015) as antimicrobials and antifungals, and even with antioncogenic activity. Many endophytes belong to the fungi Ascomycetes and Actinobacteria and produce metabolites which are inhibiting human pathogens and parasites (KLIMOVAMARTINEZ et al, 2017).

\section{Uses in Agriculture}

\section{Abiotic and biotic stress resistance}

Endophytic bacteria have beneficial effects on their host, for example some stimulate plant growth and metabolism (MILIUTE et al, 2015) and can improve resistance to phytopathogens like Bacillus strains (FENDRIHAN et al, 2016). The same authors presents a list of main agricultural crops and bacterial endophytes founded inside them, many of which being Proteobacteria, Firmicutes and Actinobacteria. These can enhance the resistance of host plant to abiotic and biotic stress, including drought and salinity stress by inducing accumulations of glycine betaine, a well-known compatible solute (JHA et al, 2011).

\section{Microorganisms in Pests and disease control}

One of the major problems in agriculture is the threat of pathogens and pests which produce damages and crop loss. A possible solution is the use of microorganisms or their secondary metabolism products. Pseudomonas fluorescens CHA0 strain produces 2,4-diacetyl phloro glucinol (2,4-DAPG) and pyoluteorin, which can have 
a noticeable influence in reducing eggs hatching of Meloidogyne javanica, a root dammaging nematode, furthermore it leads to mortality of larvae in tomato plants (SIDDIQI et SHAUKAT, 2003). In potato tubers, some reseachers have founded bacteria from Bacillus, Pseudomonas, Rhodococcus, Serratia, Obesumbacterium and Lysinibacillus genera, some of them producing siderophores antibiotics, some like $S$. plymuthica A30 strain has antagonist activity against Dickeya sp. (CZAJKOVSCKI et al, 2012). The fight against Rhizoctonia solani, a pathogenic fungus that caused significant crop losses, stimulated the use of biological control. Experiments performed with Alternaria longipes, Epicoccum nigrum, Phomopsis sp., and Trichoderma atroviride, showed that T. atroviridae and E. nigrum are more effective against the pathogen (LAHLALI et HRIJI, 2010). Furthermore, two Streptomyces strains were isolated from potato plants which can be used as antagonistic to a Streptomyces scabiae, a dangerous phytopathogen (FLATLEY et al, 2015).

\section{Plant growth promoting microorganisms}

Some microorganisms can stimulate plants growth by helping them with the necesary nutrients, being nitrogen fixers, phosphate solubilizers, phytohormones like compounds producers. Strains from microbiome have PGP activity (YADAV, 2017), performing solubilization of $\mathrm{P}$, $\mathrm{Zn}, \mathrm{K}$, fixation of $\mathrm{N}$, and production of compounds with beneficial effects on plant growth such as auxins, gibberellins, or can help to reduce the level of ethylene. The same many endophytic bacterial strains were isolated from different plants from Pakistan, and some of them proved to have plant growth stimulating activity, such as producing IAA, phosphate solubilization, and some salt stress and resistance to phytopathogens (ULLAH et al, 2018). Bacterial isolates from Clerodendrum colebrookianum were able of PGP activity (PASSARI et al, 2016). Some endophytes can promote the growth of plants by releasing special metabolites thus having the potential to be of a real support for agriculture (SANTOYO et al, 2016).

Not only growth stimulators but also crop protection effects were noticed. The bacteria Enterobacter cowani, initially isolated from the surface of tomato fruits, was proved to be antagonistic for Fusarium verticillioides, Alternaria tenuissima, and Botrytis cinerea (SHI et SUN, 2017).

\section{Pharma and Medicine}

\section{Antibiotics}

The endophytes, fungi and bacteria, are producing different types of antibiotics which are used in the competition for space and food. In the same time these strains can be use in biotechnologies such as production of antibiotics for human and animals use (AMBROSE et al, 2013; AHARWAl et al, 2016). Mempara and Chandra (2013) showed that the endophytes are still an interesting topic for studying, especially for their possible applications in the production of new antibiotics and agrochemicals, these authors highlighted this interest by making a table with examples of such microorganism isolated from plants, from genera such as: Bacillus, Paenibacillus, Nocardia, Enterobacter, Pseudomonas, Streptomyces, and so on. In the early 2000 s, researches revealed the peptide antibiotic coronamycins, produced by the endophytic Streptomyces, isolated from Monstera sp. (EZRA et al, 2004). Test with chloroform treated isolates from Zataria multiflora, Achillea willhelmsii and Calendula officinalis L. showed a clear inhibition of growth of Staphylococcus aureus, Pseudomonas aeruginosa, Acinetobacter baumannii and Enterococcus faecalis strains (MOHAMMADI et al, 2016). The endophytic fungi from Melochia umbellata, not taxonomically identified, produced active metabolites with antibiotic effects revealed by test on E. coli, S. dysentriae, P. aeruginosa, and V.cholerae of the ethyl-acetate and methanol extracts (RANTE et al, 2018). Strain with antibacterial activity or antagonisitic activity from Fusarium, Aspergillus, Cladiosporium, Curvularia and Diaporthe genera, were isolated from needles (leaves) of Cupressus torulosa D.Don (BISHT et al, 2016). Cyclic lipopeptides antibiotics and antifugals are produced by a Bacillus endophytic strain HC8 (MALFANOVA et al, 2012). The actinomycetes, endophitic strains can be reliable producers of biologically active substances (MATSUMOTO et TAKAHASHI, 2017). The authors isolated over 1000 of such strains from plants roots. Even from mangrove plants Porteresia coarctata (Roxb), a Penicillium crysogenum strain as endophyte was demonstrated to be able to produce an antibiotic substance, characterized by antibiogram test and mass spectroscopy (DEVI et al, 2012). The helvolic acid and derivates with power full antifungal and antibacterial activity were isolated from the fermentation substrate of an endophytic Fusarium which was isolated from Ficus carica leaves (LIANG et al, 2016). Fungal extracts obtained from endophytic fungi (Aspergillus niger, A. japonica, A. repens, Alternaria tenuissima, Fusarium solani, F. semitectum, Drechslera australia) were effective against pathogenic bacteria Bacillus subtilis, Klebsiella pneumoniae, Esherichia coli, Salmonella typhi murium, Staphylococcus aureus (SINGH SADHU et al, 2015). From Curcuma mangga a medicinal plant, 142 endophytic fungi were isolated and $66 \%$ showed antibiotic activity, the best results being with fungi cultivated on PDA suplemmented with powder obtained from the host plants (MUAZZAM et al, 2015). 


\section{Antiviral products}

The endophytic fungi Cytonaema is able to release antiviral products (cytonic acids A, B) against human cytomegalvirus which are inhibiting its protease (GUO et al, 2000; JALGAONWALA et al, 2011). Both bactericidal and fungicidal effects were observed with the use of methanolic extracts from the endophytic fungus Colletotrichum gloeosporioides, with a particular interest in the antibiotic resistant $S$. aureus growth (ARIVUDAINAMBI et al, 2011).

\section{Anticancer drugs}

Taxomyces andreanae is a fungus associated with Taxus baccata, demonstrated to participate at the production of taxol, an anticancer compound, which is produced by the host plant as well (PRAKASH et al, 2016). The endophytic fungi Pestalotiopsis microspora isolated from braches of Taxus chinensis produces $\alpha$-pyrone derivatives, having cytotoxic activity against HeLa and Casky cell lines (LI et al, 2015).

\section{Antidiabetic effect}

Some endophytic fungi of 6 plants found in exotic areas (Swietenia mahagoni Jacq., Andrographis paniculata Ness., Orthosiphon spicatus BBS, Morinda citrifolia L., Piper crocatum L. and Piper ornatum sp) prove to produce compound with antidiabetic effects (DOMPEIPEN et al, 2011), the effects were revealed by the alfa glucosidase test, in which the compounds inhibited the enzyme activity, therefore showing potential in lowering the blood sugar level as the enzyme hydrolyzes carbohydrates into sugar.

\section{Others}

Three enzymes were obtained from endophytic fungi and from a mushroom, showing fibrinolythic activity (NOOR et al, 2016). FH3, produced by a strain of Fusarium sp., of $34 \mathrm{kDa}$, and S13 of the same mol weight produced by the strain Penicillium citrinum.

\section{Industry}

\section{Production of enzymes}

Many useful enzymes for human actvities are practically produced by bacteria and fungi from water, soil and plants, and they can be a source or precursors for useful products (DINIZ ALVEZ et al, 2014). The endophytic strains can produce for example: gellatinases, caseinases, esterases, CM cellulases and amylases (hidrolythic enzymes) with a broad range of applications.

\section{Environment protection}

The endophytic bacteria belonging to genera Rhizobium, Pseudomonas, Stenotrophomonas, and Rhodococcus, isolated from Lotus corniculatus and Oenothera biennis that can grow in heavy polluted area are able to degrade hydrocarbons, and have plant growth promoting properties (PAWLIK et al, 2017).

The endophytes can also be used for bioremediation as they can metabolize greenhouse gases (STĘPNIEWSKA et KUŹNIAR, 2013). A Pantoea strain from rice rhizosphere is able to reduce the arsenium uptake by rice host, inducing its resistance against this element (LAKSHMANAN et al, 2016), other bacteria, for example Pseudomonas chlororapis, is able to inhibit the fungi Magnaporthe oryzae, thus concluding that there are many plant associated microbes, useful for agriculture and environmental protection, another example being Pennisetum in which rhizosphere was identified a strain of Stenotophomonas maltophila that can degrade the organophosphate pesticide chlorpyrifos residues from soil (DUBEY et FULEKAR, 2012).

\section{Conclusions}

The cases presented here represent only a small fraction of the discoveries and experiments that took place in the last few decades allover the world regarding the plants associated microorganisms. They prove the tremendous potential of the biotechnologies using microorganisms from the environments, which will have more developments and applications in the years to come, in order to underpin the sustainable development. A focus will be the bioscreening for new useful microbes, and to set up new techniques and biotech production based on them as an important part of the future bioeconomy, where people will have to learn to live in harmony with nature and not against it.

\section{Conflict of Interest}

The authors have no conflict of interest to declare.

\section{References}

1. AHARWAL R.P, KUMAR S., SADHU S.S. (2016) Endophyticmycoflora as a source of biotherapeutic compounds for disease treatment. J Appl. Pharm. Sci.; 6 (10):242-254.

2. AHMAD M.S, NOOR Z.M., ARIFFIN Z.Z. (2013). New Thrombolytic Agent from Endophytic Fungi and Lignosus rhinocerus. The Open Conference Proceedings Journal; 4, (Suppl-2, M22):95-98.

3. AMBROSE C., VARGHESE C., BHORE S.J. (2013) Endophytic bacteria as a source of novel antibiotics: An overview. Pharmacognosy Reviews; 7(13): 11-16.

4. ARIVUDAINAMBI U.S., ANAND T.D., SHANMUGAIAH V., KARUNAKARAN C., \& RAJENDRAN A. 
(2011) Novel bioactive metabolites producing endophytic fungus Colletotrichum gloeosporioides against multidrug-resistant Staphylococcus aureus. FEMS immunology and medical microbiology, 61(3), 340-345. https://doi.org/10.1111/j.1574-695X.2011.00780.x

5. BISHT R., SHARMA D., AGRAWAL P.K. (2016) Antagonistic and antibacterial activity of endophytic fungi isolated from needles of Cupressus torulosa D.DON. Asian J Pharm Clin Res; 9(3):282-288.

6. BULGARELLI D., SCHLAEPPI K., SPAEPEN S., LOREN VAN THEMAAT E., SCHULZE-LEFERT P. (2015) Structure and Functions of the Bacterial Microbiota of Plants Annu. Rev. Plant Biol.; 64:807-38.

7. CZAJKOWSKI R., DE BOER W.J., VAN VEEN J.A., VAN DER WOLF J.M. (2012) Characterization of bacterial isolates from rotting potato tuber tissue showing antagonism to Dickeya sp. biovar 3 in vitro and in planta, Plant Pathology; 61: 169-182.

8. DESALE MONALI G., BODHANKAR M.G. (2014) Antimicrobial Activity Of Endophytic Fungi Isolated From Ocimum Sanctum Linn, Am J. 1(3) AIJCSR-178 ISSN 2349-4425. www.americanij.com

9. DEVI P., RODRIGUES C., NAIK C.G., D'SOUZA L. (2012) Isolation and Characterization of Antibacterial Compound from a Mangrove-Endophytic Fungus, Penicillium chrysogenum MTCC 5108. Indian J Microbiol.; 52(4):617-623.

10. DOMPEIPEN E.J., SRIKANDACE Y., SUHARSO W.P., CAHYANA H., SIMANJUNTAK P. (2011) Potential Endophytic Microbes Selection for Antidiabetic Bioactive Compounds Production. Asian Journal of Biochemistry, 6: 465-471.

11. DUBEY K.K, FULEKAR M.H. (2012) Chlorpyrifos bioremediation in Pennisetum rhizosphere by a novel potential degrader Stenotrophomonas maltophilia MHF ENV20. World J Microbiol Biotechnol.; 28:1715-1725.

12. EZRA D., CASTILlO U.F., STROBEL G.A. et al. (2004) Coronamycins, peptide antibiotics produced by a verticillateStreptomyces sp. (MSU-2110) endophytic on Monstera sp. Microbiology; 150 (4):785-93.

13. FENDRIHAN S., CONSTANTINESCU F., SICUIA O.A., DINU S. (2016) Beneficial Bacillus Strains Improve Plant Resistance to Phytopathogens: A Review. International Journal of Environment Agriculture and Biotechnology.; 1(2):137-142.

14. FLATLEY A., OGLE L., NOEL A., FRALEY E., GOODMAN A., BECKER D. (2015) Isolation of Possible Biocontrol Endophytic Bacteria from Solanum tuberosum Effective Against Streptomyces scabies. (2015). Poster Sessions. Paper 7.http://commons.nmu. edu/facwork_postersessions/7

15. GAIERO J.R., MCCALL C.A., THOMSON K.A., DAY N.J., BEST A.S, DUNFIELD K.E. (2013)
Rhizosphere interactions inside the root microbiome: bacterial root endophytes and plant growth promotion. American Journal of Botany; 100 (9): 1738-1750.

16. JALGAONWALA R.E., MOHITE B.W., MAHAJAN R.G. (2011) A review: Natural products from plant associated endophytic fungi, J. Microbiol. Biotech. Res.; 1 (2): 21-32.

17. JHA Y., SUBRAMANIAN R.B., PATEL S. (2011) Combination of endophytic and rhizospheric plant growth promoting rhizobacteria in Oryza sativa shows higher accumulations of osmoprotectant against saline stress. Acta Physiol. Plant; 33:797-802.

18. LAHLALI R., HIJRI M. (2010) Screening, identification and evaluation of potential biocontrol fungal endophytes against Rhizoctonia solani AG3 on potato plants, FEMS Microbiol. Lett.; 311:152-159.

19. LAKSHMANAN V., COTTONE J., BAIS H.P. (2016) Killing Two Birds with One Stone: Natural Rice Rhizospheric Microbes Reduce Arsenic Uptake and Blast Infections in Rice. Front. Plant Sci. 7:1514. doi: 10.3389/fpls.2016.01514

20. LI X., GUO Z., DENG Z., YANG J., ZOU K. (2015) A New $\alpha$-Pyrone Derivative from Endophytic Fungus Pestalotiopsis microspora. Rec. Nat. Prod.; 9 (4): 503-508.

21. LIANG X.A., MA Y.M., ZHANG H.C., LIU R. (2016) A new helvolic acid derivative from an endophytic Fusarium sp. of Ficus carica. Nat. Prod. Res.; 30 (21):2407-2412.

22. MALFANOVA N., FRANZIL L., LUGTENBERG B., CHEBOTAR V., MARC ONGEN M. (2012) Cyclic lipopeptide profile of the plant-beneficial endophytic bacterium Bacillus subtilis. HC8Arch Microbiol.; 194:893-899.

23. MARTINEZ-KLIMOVA E., RODRÍGUEZ-PEÑA K., SÁNCHEZ S. (2017) Endophytes as sources of antibiotics. Biochem Pharmacol.; 134:1-17.

24. MENPARA D., CHANDA S. (2013) Endophytic bacteria-Unexplored reservoir of antimicrobials for combating microbial pathogens. In: Mendez-Vilas A (Ed.) Microbial Pathogens and Strategies for Combating them: Science, Technology and Education. Formatex, Badazoj, Spain, 2:1095-1103.

25. MILIUTE I., BUZAITE O., BANIULIS D., STANYS V. (2015) Bacterial endophytes in agricultural crops and their role in stress tolerance: a review. ZemdirbysteAgriculture; 102(4):465-478

26. MOHAMMADI A.M., EBRAHIMI A., MAHZONIEH M.R., LOTFALIAN S. (2016) Antibacterial Activities of Bacterial Endophytes Isolated From Zataria multiflora, Achillea willhelmsii and Calendula officinalis L. Against Some Human Nosocomial 
Pathogens. Zahedan, J. Res. Med. Sci.; 18(9):e2482. doi: 10.17795/zjrms-2482.

27. MOLINA G., PIMENTEL M.R., BERTUCCI T.C.P., PASTORE G. (2016) Application of fungal endophytes in biotechnological processes. Chem. Eng. Trans.; 27:289-284.

28. MOUSA K., RAIZADA M.N. (2013) The diversity of anti-microbial secondary metabolites produced by fungal endophytes: an interdisciplinary perspective. Frontiers in Microbiol. March 2013 | Volume 4 | Article 65 | doi: 10.3389/fmicb.2013.00065

29. MU'AZZAN K.A.A.R., TAUFIQ, M.M.J., NOOR A., NOORHAZIRA S., DARAH I. (2015) Screeening of antibacterial activity of endophytic fungi isolated from different leaf ages of Curcuma mangga using different growth media. Intl. J. Res. Med. Health Sci.; 5 (2):2307-2083.

30. NAIR D.N., PADMAVATHY S. (2014) Impact of Endophytic Microorganisms on Plants, Environment and Humans Hindawi Publishing Corporation. Scientific World Journal Volume 2014, Article ID 250693, 11 pages http://dx.doi.org/10.1155/2014/ 250693.

31. NEWMAN, D.J., \& CRAGG, G.M. (2015). Endophytic and epiphytic microbes as "sources" of bioactive agents. Frontiers in chemistry, 3, 34. https://doi.org/10.3389/fchem.2015.00034

32. NiCOLETTI R., FIORENTINO A. (2015) Plant Bioactive Metabolites and Drugs Produced by Endophytic Fungi of Spermatophyta. Agriculture, 5:918-970.

33. NIGHAT F., TARIQ I., MUHAMMAD S. et al. (2016) Epicoccum sp, an emerging source of bioactive metabolites. Acta Pol. Pharm. Drug Res.; 73 (1):13-21.

34. PACKIARAJ R., JEYAKUMAR S., AYYAPPAN N., ADHIRAJAN N., PREMKUMAR G., RAJARATHINAM K., MUTHURAMKUMAR S. (2016) Antimicrobial and cytotoxic activities of endophytic fungus Colletotrichum gloeosporioides isolated from endemic tree Cinnamomum malabatrum. Studies in Fungi; 1 (1): 104-111.

35. PAGENI, B.B., LUPWAYI N.Z., AKTER Z., LARNEY F.J., KAWCHUK L.M., GAN, Y. (2014) Plant growth-promoting and phytopathogen-antagonistic properties of bacterial endophytes from potato (Solanum tuberosum L.) cropping systems. Can. J. Plant Sci.; 94: 835-844.

36. PARSA, S., ORTIZ V., VEGA F.E. (2013) Establishing Fungal Entomopathogens as Endophytes: Towards Endophytic Biological Control. J. Vis. Exp. (74), e50360, doi:10.3791/50360
37. PAVITHRA N., SATHISH L., AANDA K. (2012) Antimicrobial and Enzyme Activity of Endophytic Fungi Isolated from Tulsi. J. Pharm. Biomed. Sci. JPBMS; 16 (12).

38. PAWLIK, M., CANIA, B., THIJIS, S., VANGRONSVELD, J. and PIOTROWSKA-SEGET, Z. (2017) Hydrocarbon degradation potential and plant growth-promoting activity of culturable endophytic bacteria of Lotus coriculatus and Oenothera biennis from a long term polluted site. Environmental Science and Pollution Research. 1-13.

39. PIMENTEL R.M., MOLINA G., DIONISIO AP, MAROSTICA MR. JUNIOR, PASTORE GM. (2011) The Use of Endophytes to Obtain Bioactive Compounds and Their Application in Biotransformation Process SAGE-Hindawi Access to Research Biotechnology Research International; Article ID 576286, 11 pages doi:10.4061/2011/576286

40. PRAKASH V. (2015) Endophytic fungi as resource of bioactive compounds. Int J Pharm Bio Sci; 6(1): 887-898.

41. PRAKASH V., RANA S., SAGAR A. (2016) Taxomyces andreanae: A source of anticancer drug. International Journal of Botany Studies. 1(3):43-46

42. RADO R, ANDRIANARISOA B, RAVELOMANANTSOA S, RAKOTOARIMANGA N, RAHETLAH V, FIENENA FR, O ANDRIAMBELOSON. (2015) Biocontrol of potato wilt by selective rhizospheric and endophytic bacteria associated with potato plants. AJFAND, 15 (1) 9763-9776.

43. RANTE H, YULIANTI R., EVARY YM, HARDIANA E. (2017) Isolation and antibacterial activity of endophytic fungi from Melochia umbellata (Houtt), Journal of Pure and Applied Microbiology, Vol. 11(3), p. 1313-1318. DOI: http://dx.doi.org/ 10.22207/JPAM.11.3.11

44. RUBY, J. and RAGHUNATH, M. (2011) A Review: Bacterial Endophytes and their Bioprospecting. Journal of Pharmacy Research. 4(3): 795-799.

45. SAPUTRI D.D., BINTANG M., PASARIBU F.H. (2015) Isolation and Characterization of Endophytic Bacteria from Tembelekan (Lantana camara L.) as Antibacterial Compounds. Producer. Curr. Biochem. Volume 2 (2): 77-89.

46. SARDUL SINGH SANDHU, SUNEEL KUMAR AND RAVINDRA PRASAD AHARWAL. (2015) Isolation and identification of endophytic fungi from Ricinus communis L. and their antibacterial activity. IJRPC, 2014, 4(3): Zemdirbyste-Agriculture, Vol. 102, No. 4, 611-618.

47. SHEHATA H.R, LYONS E.M., JORDAN K.S, RAIZADA M.N. (2016) Relevance of in vitro agar based screens to characterize the anti-fungal activities 
of bacterial endophyte communities. BMC Microbio$\operatorname{logy}$ (2016) 16:8. DOI 10.1186/s12866-016-0623-9.

48. SHI J.-F., SUN C.-Q. (2017) Isolation, identification, and biocontrol of antagonistic bacterium against Botrytis cinerea after tomato harvest; Braz. J. Microbiol. 706-714.

49. SHIVA KAMESHWARI M.N., MOHANA B., THARASARASWATHI K.J. (2015) Isolation and identification of endophytic fungi from Urginea indica, a medicinal plant from diverse regions of South India. Intl J Latest Res. Sci. Technol.; 4 (1): 75-80.

50. SIDDIQUI A., SHAUKAT, I.S. (2003). Suppression of root-knot disease by Pseudomonas fluorescens CHAO in tomato: Importance of bacterial secondary metabolite, 2,4-diacetylpholoroglucinol. Soil Biology and Biochemistry. 35. 1615-1623. 10.1016/j.soilbio. 2003.08.006

51. SINGH SK. (2015) Role of Endophytes in Pharmaceutical Industry, $J M B ; 4$ (1).

52. SMITH SA, TANK DC, BOULANGER L-A, BASCOM-SLACK CA, EISENMAN K, et al. (2008) Bioactive Endophytes Warrant Intensified Exploration and Conservation. PLoS ONE, 3(8): e3052. doi:10.1371/journal.pone.0003052

53. SPECIAN V., SARRAGIOTTO MH., ALENCAR P.J., CLEMENTE E. (2012) Chemical characterization of bioactive compounds from the endophytic fungus Diaporthe helianthi isolated from Luehea divaricata. Brazilian Journal of Microbiology (2012): 1174-1182.
54. STĘPNIEWSKA Z., KUŹNIAR A. (2013) Endophytic microorganisms - promising applications in bioremediation of greenhouse gases. Appl Microbiol Biotechnol. 97:9589-9596.

55. SUCIATMIH Y., SUPRIYATI D. and RAHMANSYAH, M.(2013)Biodiversity of endophytic bacteria and their antagonistic activity to Rhizoctonia solani and Fusarium oxysporium. Global journal of biology and health sciences, 2(4):111-118.

56. ULLAH A, MUSHTAQ H, USMAN ALI, HAKIM, EHSAN ALI, MUBEEN S. (2018) Screening, isolation, biochemical and plant growth promoting characterization of endophytic bacteria. Microbiol Curr Res.; 2 (2): 24-30.

57. YADAV A.N. (2017) Agriculturally Important Microbiomes: Biodiversity and Multifarious PGP Atributes for Amelioration of Diverse Abiotic Stresses in Crops for Sustainable Agriculture. Biomed J Sci\& Tech Res, Biomedical Research Network+, LLC, vol. 1(4), pages 861-864, September. DOI: 10.26717/BJSTR.2017.01. 000321

58. YIN et al. (2015) Bioactive Compounds from Aspergillus terreus MP15, an Endophytic Fungus Isolated from Swietenia macrophylla Leaf. Malays. $j$. med. biol. res. Volume 2, No 3/2015 (262-272). ISSN 2313-0016

59. YONEBAYASHI K., KATSUMI N., NISHI T., OKAZAKI M. (2014) Activation of Nitrogen-Fixing Endophytes Is Associated with the Tuber Growth of Sweet Potato. Mass spectrometry, Vol. 3 (2014), A0032. doi: 10.5702/massspectrometry.A0032 